\title{
Deliberative Politics through Citizens' Participatory Democracy: A model for Africa Political Processes
}

\author{
Andrew Osehi Enaifoghe \\ Department of Public Administration, University of Zululand KwaDlangezwa, South Africa \\ andyransey@gmail.com
}

\begin{abstract}
This article explores the present crisis of democratic governance or administration in Africa and examines the elective capability of deliberative majority rules system of democracy, in which the desire of the general public is educated by mindful, engaged citizen's commitment and conversation. There are various questions needing answers; are the various and spellbound citizenry even equipped for consultation? How likely is amass thought of deliberation to achieve a very much contemplated choice? Wouldn't it gather consultation reproduce a similar power lopsided characteristics blocking different sorts of talk? Deliberative models are displayed in principle and practical discourse, with contextual investigations including the furious populism of the Brexit vote, the ascent of deliberative components. What the contributing creators do share is the acknowledgement that the authenticity of appointive portrayal or representatives endures when individuals in the majority rule system of governments end up frustrated, disillusioned, and repelled. This study gives challenging and convincing thoughts regarding how to re-establish confidence in popular democratic governments by making them stronger and responsive. This study adopted a qualitative method of analysis.
\end{abstract}

Keywords: Deliberative; consultation; direct participation; commitment; societal imbalances, politics

\section{Introduction}

Democracy in Africa can be said to be under siege and politics has become a dirty game, for this conceived thoughts, therefore, a lot of people tend to have virtual deliberation on politics and burning political issues, rather than participating in actual politics that is why many people believe that democracy is one of the worst things that had happened in the continent of Africa. Since those who deliberate on politic fail to participate actively. The famous Stalin once said 'those who vote decide nothing,' but those who conduct elections are the ones who decide everything because they are players. The beautiful game of politics is however shamefully played with dirty hands. Quite frankly one may be curious to conclude that democracy is a misfit for Africa. Maybe Africa is yet to be mature for democracy to strive well. Looking back to history and as a common knowledge Africa old ways of life during culture practice with values a communal system of living with a monarchical system. It was mostly practiced and still being practiced in Africa particularly in the western part of Africa which include Nigeria and Ghana, with the existence of the Oba (king)-apparently there were the Oba (more like an emperor), the village kings, chiefs, the warrant chiefs, village heads, community leaders, heads of household, youth leaders and group leaders within each community. This was regarded as an indirect rule system long before Lord Lugard allegedly introduced it in Nigeria (who became the father of indirect rule system). The chain of political leadership had existed long before the European contact with Africa, particularly in the ancient city of Benin (Nigeria) the cradle of black civilization, history records that the then Oba had developed and practice indirect rule system through the kings and chiefs.

However, critics of deliberative politics argue that in light of the fact that societal imbalances can't be sectioned in deliberative settings the deliberative procedure unavoidably propagates these disparities (Rowe and Frewer 2005). Therefore, they contend, consideration does not fill its conjectured needs, yet rather delivers misshaped discourse dictated by disparities, not merits. Promoters of deliberation must face these reactions, like do less-special, less-taught, or maybe unskilled members stand a possibility in exchanges with the more favored, better instructed, and articulate. Could their contentions ever be seen or weighed similarly? Deliberative democracy system is primarily about subjects or citizens being given satisfactory time, information and support to ponder the issues, and direct impact over organization arrangements and projects. The commitment is tied in with putting citizens closer to the issues of government. Deliberative vote based system of democracy is not the same as representative government since it puts discussions, different viewpoints and comprehension at the focal point of the choice instead of depending on surveying and casting of the vote through elections. It underlines information handling as much as sharing information and urges 
individuals to fundamentally test weigh up and think about the scope of viewpoints, information sources and proof. It is an elective way to deal with 'asking individuals what they think when they're not considering', which inspires clueless reactions. Rather, deliberative methodologies look to evoke educated, quality, important results.

However, the new shape that has been by a long shot the best is deliberative majority rule system of government. According to Dryzek (2007), deliberative majority rule system of government presently comprises the most dynamic area of political hypothesis completely -not simply a democratic theory. Amazingly, vast developing writing, both hypothetical and experimental, on deliberative system of participatory democracy, has its impact spread far outside colleges. In the 1960 s protectors of a participatory origination of vote based system of democracy, had a politically dynamic citizenry at its disposal, who criticized defenders of a realistic democracy hypothesis. In light of discoveries from the exact reviews demonstrating that most people were politically latent and needed enthusiasm for information regarding governmental issues, deliberations of thoughts regarding subjects' support ought to be modified as needs be. Subject lack of care was viewed as practical for the equitable framework (Goodhart et al., 2011). Around 1980s the consideration and attention of most political scholars turned in different ways, the enthusiasm for the majority rule system of democracy hypothesis wound down and, specifically, participatory, equitable hypothesis ended up unfashionable.

Since theories of democracy appreciate such an incredible restoration, an undeniable inquiry is to whether there is still a place for the participatory hypothesis, or is it now antiquated and outmoded? On its essence, we appear to be in a great time for participatory majority rule system of government - democracy. Deliberative vote based system of democracy is a type of subject support, and over the previous decade enthusiasm for participatory administration has grown tremendously (Goodhart et al., 2011). Sometime in the 1980s participation in political issues started to end up some portion as standard advancement practice. In the year 1996, the World Bank distributed a Participation Sourcebook (World Bank, 1996). Perhaps most strikingly, models of participatory planning have been spreading the world over from its cause in Brazil. Or on the other hand, at any rate, measures called participatory planning have been multiplying. Give me a chance to state now just that the expression "investment" is utilized to cover an extensive variety of different activities (Rowe and Frewer 2005). In 2007, the World Bank issued a Report on Participatory Budgeting (Shah 2007). The contemporary help for participation by governments, official bodies, and NGOs is in striking difference to support during the 1960s, which was advocated by prevalent developments in rich nations.

In various Western nations, an assortment of grassroots political developments were effectively requesting more participation and more noteworthy majority rules system of democracy; this was the season of Rudi Dutschke's well-known necessitate 'the long walk through the organizations.' The current design for deliberative majority rules system of democracy started as a political hypothesis-driven activity, as in it was deliberative vote based proposition that rose first during the 1990s and was trailed by observational investigations. It further became the structure of exceptional deliberative gatherings, generally where a deliberative democrat indicated little enthusiasm for the most recent thirty years of participating advancement. Much of the experimental examination centred on the procedure of consideration among members in the new deliberative bodies. In addition, in so far as deliberative democrats appreciate models of participatory majority rule system of government, they normally regard them as precedents of deliberative vote based system of democracy. Despite Dennis Thompson's conviction that the move in the direction of deliberative hypothesis has not dislodged participatory theory, (Thompson, 2008, 512), the pervasive view, though not constantly made express, is by all accounts that deliberative vote based system of democracy has now surpassed and subsumed its forerunner.

Deliberative majority rules system of democracy has, for instance, been viewed as 'participatory democracy regeneration (Fung and Wright 2003, 40), and the case made that 'deliberative democrats have a tendency to be participatory democrats, too (Goodin 2008, 266). Participatory majority rules system of democracy is rather unique in relation to deliberative vote based system of democracy. Pondering, exchange, and discussion is vital to any type of majority rules system of government, including participatory system of democracy. Yet on the off chance that consultation is fundamental for vote based system of government is not adequate. To some degree of the more eager champions of deliberative majority rules system tend to exhibit 
pondering as though it were synonymous with vote based system democracy itself. The speed and excitement with which deliberative vote based system democracy has been taken up so generally is, in itself, rather exceptional. Mutz (2008), remarked that the "measure of time and cash put resources into it by governments, establishments, and national gatherings are stunning with respect to for all intents and purposes some other current sociology theory (Mutz 2008,535). The question now is what are such a significant number of individuals so eager about?

\section{Review: Conceptualization of Deliberative Democracy}

Vote based system of democracy is a subject that crosses the limits in political theory, and in my own field of political hypothesis, there has been a noteworthy restoration of democratic hypothesis or theories. In a political hypothesis, there are arguments that 'vote based system of democracy' is typically presently qualified by one of a variety of descriptive words, which incorporate cosmopolitan, agonistic, republican, and monitory. The literature in deliberative politics with various arguments and precedents makes the significance of deliberative vote based system of democracy difficult to bind. In this study, the motivations are sufficient to feature the focal case of deliberative equitable scholars; that people ought to dependably be set up to defend their moral and political arguments with substantial reasons, and be set up to think and deliberate with others on the reasons they give. There is currently a broad hypothetical discussion about what appropriately considers as 'deliberative,' quite a bit of which has been carried out at a genuinely unique level. Significantly, this discourse is the empirical side of deliberative vote based system of democracy. Democracy system of government is under attack, according to James and Mansbridge (2017), the measure of perceived democratic nations on the planet is never again extending after the purported Third Wave of law based transitions (Samuel, 1991).

Indeed, there is something of a "vote based recession (Larry, 2015). Some obviously democratic nations with focused elections are undermining components of liberal majority rules system of democracy: the rights and freedoms that guarantee opportunity of thought and articulation, security of the standard of law, and the assurances for the substructure of common society that might be as imperative for making vote based system democracy fill in as the constituent procedure itself (Steven and Lucan, 2010). The model of gathering rivalry based vote based system of democracy-the vital model of vote based system in the cutting edge era, which appears to be under risk. However, what may be designated as 'meritocratic tyranny,' that is a model in which administrations with defective just procedures, that give good governance, is drawing in consideration and some support. Singapore is the main effective surviving precedent, although some recommend China as another country moving toward this path. Open discontent makes assist challenges for the focused model. A vote based systems of democracy around the globe battle with the clear bay between political elites who are broadly questioned and prepared subjects who fuel populism with the vivacity of furious voices. Baffled residents betraying elites have delivered unforeseen results of elections, including the Brexit choice and the 2016 U.S. presidential elections.

James and Mansbridge (2017) stated that contending groups' intention is to win, are keen on advising voters just when it is further bolstering their advantage. The method of reasoning for aggressive majority rule system of government, the most compelling model created by the late financial analyst Joseph Schumpeter, held that similar procedures of promoting utilized in the business circle to inspire individuals to purchase items can be normal in the political circle. On this view, we ought not to expect an "honest to goodness" open will, but instead "a made will" that is only a side-effect of political competition (Joseph, 1942). However, the perfect idea of vote based system of democracy as the standard of "the general population" is profoundly undermined when the desire of the general population is in extensive part fabricated. The authenticity of the majority rule system of government relies upon some genuine connection between general society will and people in general strategies and elected office-holders. Nevertheless, some have reprimanded this "society hypothesis of popular government" as observationally gullible it's extremely status as a people hypothesis reflects how across the board this regulating desire is in actual fact (Christopher and Larry, 2015). To the degree that elected leaders produce the will of the people, the regularizing causal bolt goes off course. On the off chance that present majority rules systems of democracy can't deliver significant procedures of people's will arrangement. 
The authenticity cases of meritocratic dictatorships or considerably more completely imperious frameworks turn out to be similarly stronger (Princeton, 2015). Most recently, according to Pateman (2012), another way to deal with majority rules system government has turned out to be progressively conspicuous. In view of more prominent consultation among general society and its representatives, deliberative politics and democratic system has the potential, from a certain perspective, to react to the presence of the current difficulties. On the off chance that the numerous renditions of a more deliberative democratic government satisfy their goals, they could help restore majority rule system authenticity, accommodate more legitimate will of the people policy, then give a centre ground between broadly questioned elites and the furious voices of populism, and therefore help satisfy a portion of the basic regularizing assumptions regarding vote based system of democracy. The question is, what means can deliberative majority rule system of government if it somehow managed to fill in as visualized by its supporters, react to the difficulties outlined above?

To respond to it, Pateman (2012) suggested that if the more deliberative organizations that many advocates, can be connected to genuine choices in real continuous vote based systems, seemingly they could positively affect authenticity and prompt better administration. In this way, they could improve the relationship between the general society's genuine concerns and how they are represented. Secondly, these organizations could help fill the gap between doubted elites and furious populists. Elites are questioned to a limited extent since they appear and frequently are lethargic to general society's worries, expectations, and qualities. Furthermore, deliberative vote based strategies open up the possibility of prescriptions that are representative of the whole people and dependent on the calm, proof-based investigation of the benefits of contending arguments. Prominent deliberative foundations are grounded in general society's qualities and concerns, so the voice they amplify isn't the voice of the elites. In any case, that voice is generally likewise, after consideration, more proof based and intelligent of the benefits of the significant arrangement contentions. Subsequently, these organizations fill a vital hole. The issue which incorporates changing definitions, methodologies, and settings, the root idea is that consultation requires "gauging" contending arguments for approaches or hopefuls in a setting of commonly affable.

Various discourses in which individuals can choose the benefits of arguments with substantial information the most punctual work on deliberative majority rule government started by examining legislatures (Joseph, 1994), in this issue, Cass Sunstein, interestingly, takes a gander at consideration among policy-makers in the official office. Bernard Manin looks outside government discussions and open public gatherings that can enhance the deliberative nature of battles and discourse among the general public, and therefore develop what is called the mini-public method. The fundamental reason for a mini-public methodology is that if the arbitrary example that is assembled to ponder and or deliberate is illustrative of the populace, and in the event that it is deliberated under good conditions, at that point its considered judgments after consultation ought to speak to what the bigger populace would think whether by one way or another those nationals could take part in comparably good conditions for thinking about the issue. An extraordinary arrangement relies upon the mini-public really being representative and on the record of good conditions to which it is uncovered. At whatever point the utilization of deliberative vote based system relies upon an arbitrarily elected mini-public, that application raises the issue of the level of strengthening.

\section{Materials and Methods}

This study adopted a documentary analysis method which allows researchers to study and basically consult, and make sense of written materials or documents which may be available either in the public or private domain (Mogalakwe, 2006). The above definition recommends that researchers determine the relevance of the documents that they consult on the basis of their significance to the study. Furthermore, Dey (2005, p.105) argues that in the documentary analysis, the criteria for selecting documents, or for focusing on particular extracts, should reflect the issues on which the researcher is seeking evidence. This method made it possible for the researchers to explore why deliberation is worth it. Once conducted effectively, a deliberative procedure can prompt new answers for the most difficult issues we confront, enhance approach results and cause trust among citizens and government. These procedures draw on aggregate insight and result in choices that are better, as well as are better upheld by the extensive general public. They construct shared duty, implying that the results of these procedures will probably 'stick'. Deliberative procedures are not just representatives and more gainful than non-deliberative commitment exercises; they are likewise less ill- 
disposed, removing the governmental concerns from the issue. Deliberative majority rules system of democracy has various, continuous and frequently trans-developmental advantages that include: expanding members' levels of information about issues - more comprehensively, bringing about more educated, considered perspectives being shared, developing trust among experts and networks community, building urban limit and ability, and expanding general levels of municipal commitment and political cooperation.

Citizen's Participation Role in Political Process: The question of; is there a role for deliberation about electoral rules by the youth? Though some people would give the appropriate response to be "no". For them, the idea of principled dialogue educated via cautious reflection is profoundly ambiguous with the dingy routine with regards to legislative issues. Legislative issues, so they would state, is fixated on the quest for political power. Political gatherings and lawmakers, thusly, are absolutely self-intrigued actors doing 'whatever it takes' to get the reins of intensity and utilizing that control for their fanatic advantages. The usual way of doing things is one of the strategic maneuvers and dealing, not consultation.

The Myth and the Veracity of Electoral Process: In the event that these perspectives were conceivable, they ought to be seen most unmistakably in the tenets of the electoral diversion - the direction of elections. Regards to electoral democracies in governments like Australia, there are underlying principles that set the terms of the contest for political position and leadership (power). With such a great amount in question, it would be expected that as indicated by the paradigm of self-intrigue for predominant gatherings to fix these tenets to support them. It is baffling at that point to find the commonness in Australia for example of the discourse of elections to be "free and fair", even among the political class. Considerably additionally astounding is that Australia's constituent framework does, in key regards, accommodate "free and fair decisions of elections. Take two models for which Australia is universally famous: first, the secret vote, which is globally referred to as the 'Australian poll' as it was spearheaded, which advances free elections for voters; the second, is the unbiased organization of electoral standards by the independent electoral commissions, an essential condition for credible free and fair elections.

The Ethical Stand of Electoral Process: Apparently, there is a need for a more nuanced comprehension of the job of deliberative politics. Standards and partisanship locate a place in participatory democracy and governmental issues, with the laws reflecting both. In this regards, if standards are critical to governmental issues, so is consultation, not minimum for its capacity by and large to sift through empty talk and all the more obviously outline the legitimate, rather than ill-conceived, self-enthusiasm of political actors. Instead of being an anathema to the handy substances of gathering governmental issues, deliberative politics lies at its heart. Defining the job of consultation in legislative issues isn't the equivalent, obviously, as acknowledging it in practices. Through standardized gatherings for such deliberations are imperative, particularly in connection to elections control. In a parliamentary vote based system like Australia for example, parliaments are vital to giving such discussions.

Another vital point is working together there is a need to standardize discussions for deliberating electoral regulation beyond the parliamentary setting. This is the basic that led to the foundation and the establishment of the Electoral Regulation Research Network. Its central reason for existing is to encourage trade and dialogue among constituent commissions. This goal is maybe significantly less demanding to the state than to accomplish. The institutional setting of constituent regulations is a bit complex. Diverse gatherings have shifting capacities: the essential errand of the constituent commissions is to direct electoral control; political gatherings and legislators look to propel their ideological plans through voting of elections, and scholars in this field see electoral regulation as a question of the study. The standards of autonomy and lack of bias are vital in electoral commissions, while the invigorating standards of political gatherings are those of political contestation, a blend of partisanship and ideological convictions.

To What Benefit is Citizen Deliberation in Participatory Democracy? Regards to deliberative politics in electoral and constituent control, the research on this theme, the changing capacities and standards can offer ascent to various benchmarks of pertinence, the question is, Is there enough academic enthusiasm for the inquiry? Does it make a difference as far as voter intrigue? Such assorted variety does not, in any case, spell crush. Thought neither surmises nor does it normally deliver an ensemble of unanimity. Despite what might be expected, it is continued and sustained by the outflow of assorted perspectives. Contradiction is the 
beginning stage and perpetually the end purpose of consultation. The ethicalness of consultation is that it holds out the guarantee of contradiction being grounded on a more principled premise. Deliberative politics on constituent regulation will require a "meeting ground" where alternate points of view are esteemed and heard. This suggests prudent determination of themes of shared concern. Strains will definitely emerge in the process. However, on the off chance that the speculative chemistry of thought works its belongings, these will be gainful pressures prompting the widening of skylines and deferential learning.

Deliberative Engagement and Principles of Deliberative Engagement: In deliberative politics, the standards of deliberation can be connected to the scope of settings and arrangements. Deliberative procedures include: Citizen Juries, Participatory planning, Deliberative boards and discussions, Deliberative standards and methodologies can likewise be incorporated into a scope of different forms of commitment exercises. Deliberative procedures are worked around, the supposition that the procedure will have an abnormal state of impact over results or choices. Members will approach the information they need to have an in-depth discussion and adequate time to think about that data of information. Members are chosen arbitrarily, and they represent the more extensive network of community and comprehensive of everything being equal.

Citizen and Deliberative Democracy Process: Theoretically, not much has been said about the debate on deliberative politics with two imperative questions of; where deliberation is to happen or held. Deliberative majority rules system of democracy has been held to incorporate, for instance, arriving at a consensus, network community policing, deliberative surveying, community discussions, residents' juries, nationals' gatherings, lawmaking bodies, legal bodies and participatory planning. The second is what is the point of consultation? Its points have been held to incorporate, for instance, touching base at an agreement, settling on a choice, or uncovering how people's inclinations may change after they have deliberated.15 This study believes deliberative vote based system of democracy pay attention to subjects' juries and natives' congregations. Both are models of the exceptionally made in a democratic gathering and, in both, the members arrive at a choice toward the end of their considerations. These are occasions of what at present much of the time called scaled down publics; in other words, they are made out of a gathering of citizens "little enough to be truly deliberative, and representative enough to be truly just (Goodin and Dryzek, 2006, 220). Some of the features expected in a deliberative democracy in deliberative politics (particularly with citizens' juries and citizens' assemblies).

The participants are picked by (nearly) irregular choice to guarantee not just that there is no orderly avoidance of any piece of the populace yet additionally that people with specific attributes are incorporated. Deliberation is guided by facilitators and, to enable them to end up educated and to help their consideration, the members get uncommonly arranged data and hear proof from, and question, master observers. More so, at the conclusion of their consultation, the members reach a decision about the current issue and set up a report and proposals. There are likewise some vital contrasts between citizens' juries and citizens' congregations. It is imperative to note that Citizen or Subjects' juries started around the 1970s in the US yet have been utilized considerably more broadly and as often as possible since the 1990s, especially in the UK. A citizens or natives' jury generally contains about 12-24 residents. Once in a while, the members can revise their motivation. At the point when a native's jury introduces its answer to its support, the last could possibly accept their recommendation; nevertheless, few subjects'. Juries presently enter an agreement with their charging body which necessitates that the last give a clarification of how it has reacted to the jury's proposals. Nationals' gatherings are considerably more late advancement, starting in Canada, British Columbia, in 2004.

Two more have along these lines been held in Ontario (2006), each of the three was dispatched by their individual governments with a charge to audit their electoral frameworks and to suggest an option. The three gatherings have been examined in detail from their beginnings to their decision (Warren and Pearse, 2008). It is expected a small group of the general public are a charming development. This study presents the need to make deliberative politics; recognizable feedback that is regularly brought against contentions for more prominent national inclusion in governmental issues, most people are not adequately fit for doing as such or are not intrigued. There is a possibility that numerous individuals may be pulled in by support, according to Warren $(1996,243)$, this is called 'romantic dogma'. Despite what might be expected, the exact proof from scaled down publics demonstrates that subjects both welcome and appreciate the chance to partake and to 
think, and that they consider their obligations important. Findings demonstrate that common subjects, given some information and time for exchange in gatherings of various sentiments, are very equipped for understanding complex, and some of the time specialized, issues and achieving relevant decisions about huge public issues. In addition, they need to legitimize their thinking in their reports.

The 2005 and 2009 crusades in British Columbia and the 2007 battle in Ontario unfurled without the fighting political gatherings talking about the change recommendations in any important way. None of the real gatherings embraced the get-together suggestion, not by any means the individuals who had started the change venture. Thus, inclusion of discretionary change in the daily papers generally "comprised of standard elections articles," that incorporated a comment toward the end that there was likewise going to be a submission on electoral change (Fournier et al., 2011,138). While the issue of attention is, maybe, generally effectively open to cure, one part of natives' juries is substantially harder to settle. The juries at worst case scenario are minimal more than centre gatherings, or they end up helpful legitimating gadgets for an effectively chosen approach. In no less than one case, the procedures of citizens' jury in Dublin deliberation about a proposition for a waste transfer incinerator were subverted by the City Manager's Office, which "boycotted the occasion and declined to take an interest in any capacity". In other words, they are not coordinated into the general arrangement of delegate government or majority rule system of organizations, nor do they move toward becoming a piece of the customary political cycle in the life of a network community.

\section{Discussion of Findings: Deliberative Majority Rules System of Democracy}

A deliberative majority rules system of democracy still leaves unblemished the regular institutional structures and political importance of "popular democratic government." Participatory vote based system is frequently regarded as simply regularizing contention, worried about standards and ideals. In an exceptionally huge inversion of the standard example of political cooperation and participation, citizens with poor background usually shape a substantial proportion of members; ordinarily, they are underestimated. In Porto Alegre, it is the poorer residents as opposed to the happier who partake in political debates through deliberative politics. There are various instances of the classification "community assets at the local and city level." For instance, with the help of the UN, an advancement venture was set up in the year 2000 in Bangladesh, which gave a yearly block grant (about $\$ 6,000$ ) to the most reduced level of local government (Pateman, 2012). In order to achieve this, councils were set up to sort out national planning dialogues to choose how the money ought to be designated, with the villagers isolated into small groups for discussion, with facilitators, and women's group were also created (Fölscher, 2007, 175-6). In England for instance, participatory planning and budgeting have been sorted out by local governments designating fund to their various communities for project execution for the citizens.

Citizens' gatherings are then orchestrated to discuss and choose on needs to dispense the cash. However, in a period of grimness, as is noted in the report of a national gathering on participatory planning held by the Participatory Budgeting Unit in November 2010, "specialists are presently tested to move participatory budgeting from the extra subsidies that never again exist, to center administration spending plans and assets and discourses about every one of the financial plans in a neighborhood (Pateman, 2012). Many precedents called "participatory planning" are just consultative or information sharing. Undoubtedly, similarly as great administration is superior to poor administration, so discussion or information sharing is superior to no meeting or no information. People group can profit and citizens increase some training in support in a portion of these instances of 'participatory planning and democracy,' however not very many looks to some extent like the PB that I have illustrated. However, not much had changed from over 10 years prior when one appraisal of World Bank-bolstered participatory activities expressed that "sharing of information and interview happen more as often as possible than investment in participation in basic leadership of decisionmaking (Smith 2009, 33).

Pateman (2012) noted that there is currently gigantic enthusiasm for, the discourse of, an examination into, and subsidizing of a vast assortment of investigations in interest to participate in deliberative politics, focusing, citizen consultation, and arrangement of information. The spread of 'participatory planning through participatory democracy' the world over will, in general, include estimates that fairly inquisitively and 
notwithstanding their mark, will not include the local and city spending plan. Local communities are every now and again talking about moderately little, optional sums of cash that could possibly keep on being made accessible. The greater part of the models being called participatory planning fit effectively in existing structures, and where residents do not usually take an interest, as an issue of appropriate, in choices about their city's or town's standard spending plan for accountability. A large portion of the developments misses the mark concerning participatory majority rule system of government or democracy. It was noted recently, that the bigger open circle as a space in which 'private individuals only come together as a public' (Jürgen and Thomas, 1989). That open circle ca, therefore, fill in as a place for 'basic open discussion (Jürgen and Thomas, 1989), where general feeling can shape and to which all residents could approach, with the opportunity to talk about and assemble as wanted.

He further talks about how the general public discussion could be helped through in an assortment of today's respectful society associations, including volunteer associations, holy places of worship, and academic spaces or institutions (Jürgen, 1996). Characterizing the fundamental components and concepts of liberal vote based system of democracy as "state-ness" -the state's capacity to keep up the devotion of its people and to execute focal capacities, rules and guideline of law, political rivalry, and responsibility, it has been enlightened that state-ness are the natural dangers to these key components. For instance, despite the fact that political rivalry takes into consideration gatherings and contenders to have an unmistakable and real victor, the procedure of rivalry has made an appointive need to depict candidates through their 'identities.' It has additionally urged government officials to treat their opposition as far as them versus us, in which we are great and legit and they are conniving and abhorrent. However, Pateman (2012) noted that the wild utilization of such methodologies in political battles and governmental issues all in all has fortified populist developments and made more divisiveness in the public arena.

Offe's suggestions to remedy this include reinforcing the general population's voice through different types of interest to participation and enhancing the general population's will arrangement through consideration of deliberation. He, therefore, argued that deliberation, through reason-giving, tuning in, and regarding, could deliver constructive outcomes, for example, more educated supposition, inner viability, and the capacity to augment social consideration through deliberation. This paper presents observational proof to show that, in deliberations that are organized to give a more level playing field, as imbalances in aptitude and status don't necessarily convert into disparities of impact. In the course of recent decades, we have heard a truly exceptional volume of discuss and acclaim of majority rules system of democracy, and numerous legislative, nongovernmental, and other international organizations have been occupied with popular government advancement. It was likewise proposed utilizing "haphazardness" in the arrangement of standard participation in deliberation to guarantee diversity and comprehensive portrayal.

Regardless of whether individuals intentionally consent to take an interest and deliberate 'as though" they were the same, it is just unrealistic to force deliberative balance on a social base of imbalance (Folscher, 2007). The common societal practices of people happen in deliberative settings. It must be said that the intrinsic disparities in our general public reason thought to benefit more prevailing people and gatherings while disadvantaging minority people and groups. Nevertheless, political scholar comparatively contended that "discourse that is assertive and angry is here more valued than a discourse that is provisional, exploratory, or mollifying in most real circumstances of discourse. However, this benefits the privilege of male talking styles over female (Iris, 1996). Members who are less favored might be particularly liable to share their contentions as stories. Hence, regardless of whether participants from changing financial classes deliberated together, there would be no certification that they would really tune in and comprehend each other (Iris, 1996, 2000). The applicable qualities are clear and replicable.

\section{Conclusion}

Conclusively, this study mentioned earlier some ultimate objective facts and addressing an important question. The perspective of what is occurring is that, generally, we see development of cooperation and augmentation of citizenship, yet not the beginnings of democratization and the formation of a participatory society. The historical backdrop of citizenship and the majority rule system of government are ordinarily conflated. The expression 'democratic government' is very frequently used to depict circumstances where 
just a segment of the population is conceded citizenship; the rest of, which might be a greater part, are simply subjects. However, from antiquated occasions, there is a long history of government, specifically or through delegates, by subjects over non-natives or community. It was said that majority rules system of democracy did not show up until 1893 when New Zealand received all-inclusive suffrage and in this manner, the entire population, as a right, had some part in government. The viewpoints on politics arrived a century before a large portion of the world had pursued and, even today, widespread suffrage-that exceptionally insignificant but significant necessity for democratic society, it is as yet not exactly worldwide. The battle for general suffrage was so long thus troublesome as frequently overlooked today; it is impossible that the democratization of majority rules system democracy through deliberative politics will be any less demanding in Africa as it has yielded results in other part of the world.

Commenting that Africa will be well encompassed by vote based system of democratic discourse. However in Western nations there is this popular confidence in old-built up foundations that are going out of practice, voters are repelled, therefore losing confidence in government and a wide gap has opened up among local communities and governments, and political elites as well. The voices of ordinary citizens are presently being heard uproariously in various nations, including Africa. Be that as it may, the result relies upon whether anybody is tuning in; when real spending plans on public projects and approaches are in question, political elites once in a while tune in to nationals in order parts of the world, unlike Africa. This study, therefore, suggests one method to take a gander at the new development of participation, in poor nations of Africa. It can help to enhance administration or governance, and in the developed nations it can help to reinforce the authenticity of the present framework. In the event that local citizens can take part in small public forums or can choose the dispensing of some open supports at that point, in another bit of omnipresent or ubiquitous jargon, they 'claim' those choices. In a more extensive setting, it has been contended, that the greater part of the development of interest to participate in deliberative politics through participatory democracy, it does not bother on existing foundations. Unexpectedly, from numerous points of view, it is seen as perfect ideal with the huge changes summed up as globalization. This includes a particular type of modernization that spins around auxiliary change-now being forced upon some developing and developed nations-with the commonplace formula of deregulation, privatization, and a focal job for fund capital. Such modernization blossoms with the language of "straightforwardness," and so forth, and incorporates the change of the general population area. The advancements in cooperation to participate in deliberative politics in Africa are likewise suited to the opposite side of this method of modernization, to a moderate, "sensible. Bearing in mind that citizens have the privilege to public planning, there is also the privilege to take an interest in basic leadership, about their aggregate life and to live in power structures that make such cooperation conceivable.

Along these lines, to close, the issue is not any more whether participatory democracy is possible in Africa. Unfortunately, a high level of inequality or imbalance among people who participate in participatory democracy is one of the significant difficulties to the bigger thought of actualizing deliberative democracy in Africa. This challenge must be pursued with great earnestness. Reacting to critics of deliberative politics consideration the role of disparity utilizing information from Deliberative Polls, both on the web and vis-à-vis finding far less bending than faultfinders anticipate. This offers amazing discoveries on who takes the most talking time, which has the best impact on the results, and who offers more "defended" contentions, providing explanations behind every position. Be that as it may, nobody has yet methodically contemplated the role of disparity under various citizens' deliberative politics. More research with controlled experiments could clear up this issue further. 


\section{References}

Christopher, H., Achen Larry, M. \& Bartels. (2015). Democracy for Realists: Why Elections Do Not Produce Responsive Government (Princeton, N.J.: Princeton University Press, 2015).

Offe, C. (2011). Crisis and Innovation of Liberal Democracy: Can Deliberation Be Institutionalized? Czech Sociological Review, 47(3), 447-473.

Dey, I. (2005). Qualitative data analysis. London: Routledge, Taylor and Francis Group.

Dryzek, J. (2007). Theory, Evidence and the Tasks of Deliberation. In Deliberation, Participation and Democracy: Can the People Govern? Ed. Shawn W. Rosenberg. New York: Palgrave Macmillan.

Fölscher, A. (2007). Participatory Budgeting in Asia. In Participatory Budgeting, ed. Anwar Shah. Washington, D.C.: The World Bank.

Fournier, P., Henk van der Kolk, Kenneth C., Andre, B. \& Jonathan, R. (2011). When Citizens Decide: Lessons from Citizen Assemblies on Electoral Reform. Oxford: Oxford University Press.

Fung, A. \& Wright, E. O. (2003). Thinking About Empowered Participatory Governance. In Deepening Democracy: Institutional Innovations in Empowered Participatory Governance, ed. Archon Fung and Eric Olin Wright. New York: Verso.

Goodhart, M., Fung, A., Gauri, V., Gloppen, S., Haagh, L., Heller, P., Pateman, C., Peruzzotti, E., Rudiger, A., Schmitz, P. H., Standing, G., Wampler B. \& Wing S. (2011). Democratic Imperatives: Innovations in Rights, Participation, and Economic Citizenship. Report of the Task Force on Democracy, Economic Security, and Social Justice in a Volatile World. (http://bit.ly/2011taskforce). Accessed Oct 13, 2018.

Goodin, R. \& Dryzek, J. (2006). Deliberative Impacts: The Macro-Political Uptake of Mini Publics. Politics \& Society, 34(2), 219-44.

Goodin, R. (2008). Innovating Democracy: Democratic Theory and Practice after the Deliberative Turn. Oxford: Oxford University Press.

Iris, M. Y. (1996). Communication and the Other: Beyond Deliberative Democracy, in Democracy and Difference, ed. Seyla Benhabib (Princeton, N.J.: Princeton University Press, 1996), 60-74.

Iris, M. Y. (2000). Inclusion and Democracy (New York: Oxford University Press, 2000)

James, S. F. \& Mansbridge, J. (2017). The Prospects \& Limits of Deliberative Democracy. Journal of the American Academy of Arts \& Sciences.

Joseph, A. \& Schumpeter. (1942). Capitalism, Socialism and Democracy (New York: Harper and Row, 263.

Joseph, B. (1994). The Mild Voice of Reason: Deliberative Democracy and American National Government (Chicago: University of Chicago Press, 1994).

Jürgen, H. (1996). Further Reflections on the Public Sphere, in Habermas and the Public Sphere, ed. Craig Calhoun (Cambridge, Mass.: The MIT Press, 1996), 421-461.

Jürgen, H. \& Thomas, B. (1989). The Structural Transformation of the Public Sphere: An Inquiry into a Category of Bourgeois Society (Cambridge, Mass.: The MIT Press, 1989), 27.

Larry, D. (2015). Facing Up to Democratic Recession, Journal of Democracy 26 (1) (January 2015), 141 - 155.

Mogalakwe, M. (2006). Research Report. The Use of Documentary Research Methods in Social Research. African Sociological Review, 10(1), 221-230.

Mutz, D. (2008). Is Deliberative Democracy a Falsifiable Theory? American Review of Political Science, 11, 521-38.

Participatory Budgeting Unit. (2010). Now Is the Time to Start Trusting Citizens on Budgets. (http://www. participatorybudgeting.org.uk /news-and-events/news/ now-is-the-time-to-trust-citizens-onbudgets). Accessed November 16, 2018.

Pateman, C. (2012). Participatory Democracy Revisited. APSA Presidential Address. March 2012

Pateman, C. (1989). The Patriarchal Welfare State. In The Disorder of Women: Democracy, Feminism and Political Theory. Cambridge and Malden, MA: Polity Press.

Princeton, N. J. (2015). The legitimacy of the distortions from economic inequality, see Martin Gilens, Affluence and Influence: Economic Inequality and Political Power in America (Princeton, N.J.: Princeton University Press, 2014).

Rowe, G. \& Frewer, L. (2005). A Typology of Public Engagement Mechanisms, Science, Technology, \& Human Values, 30(2), 251-90.

Samuel, P. H. (1991). The Third Wave: Democratization in the Late Twentieth Century (Oklahoma City: University of Oklahoma Press, 1991). 
Schumpeter, J. A. (1942). Capitalism, Socialism, and Democracy. New York: Harper. Service Agency Communities in One World. 2010. International Congress on Models of Participatory Budgeting. Dialog Global 24.

Shah, A. (2007). Participatory Budgeting. Washington, DC: The World Bank. (http://siteresources. worldbank.org/PSGLP/Resources/Participatory Budgeting.pdf ). Accessed March 5, 2011.

Smith, G. (2009). Democratic Innovations: Designing Institutions for Citizen Participation. Cambridge: Cambridge University Press.

Steven, L., Lucan, A. \& Way. (2010). Competitive Authoritarianism: Hybrid Regimes after the Cold War (Cambridge: Cambridge University Press, 2010).

Thompson, D. F. (2008). Deliberative Democratic Theory and Empirical Political Science. American Review of Political Science, 11, 497-520.

Warren, M. E. (1996). What Should We Expect from More Democracy? Radically Democratic Responses to Politics. Political Theory, 24(2), 241-70.

Warren, M. E. \& Pearse, H. (2008). Introduction: Democratic Renewal and Deliberative Democracy. In Designing Deliberative Democracy: The British Columbia Citizens' Assembly, ed. Mark E. Warren and Hilary Pearse. Cambridge: Cambridge University Press World Bank, 1996.

World Bank (1996). Brazil: Toward a More Inclusive and Effective Participatory Budget in Porto Alegre, $\begin{array}{lllll}\text { Volume I. Washington DC: The World } & \end{array}$ (http://www.wds.worldbank.org/external/default/WDSContent Server/WDSP/IB/2008/03/05 /000333037_20080305014411/Rendered/DF/401440v10ER0P01sclosed0March0302008.pdf). Accessed November 12, 2018. 